Article

\title{
Insights for Shaping Entrepreneurship Education: Evidence from the European Entrepreneurship Centers
}

\author{
Valentina Ndou ${ }^{1, *}$, Giustina Secundo ${ }^{1}$, Giovanni Schiuma ${ }^{2} \mathbb{D}$ and Giuseppina Passiante ${ }^{1}$ \\ 1 Department of Engineering for Innovation, University of Salento, 73100 Lecce, Italy; \\ giusy.secundo@unisalento.it (G.S.); Giuseppina.passiante@unisalento.it (G.P.) \\ 2 Department of Mathematics, Informatics and Economics, DiMIE, University of Basilicata, 85100 Potenza, \\ Italy; giovanni.schiuma@unibas.it \\ * Correspondence: valentina.ndou@unisalento.it; Tel.: +39-0832-297-923
}

Received: 6 November 2018; Accepted: 17 November 2018; Published: 21 November 2018

\begin{abstract}
The pivotal role of Entrepreneurship centers in the development of Entrepreneurship Education (EE) is receiving more attention. This study aims to open the "black box" of "how, when, why and what" entrepreneurial mindset and competencies in the field of technology entrepreneurship are learned over time in the Entrepreneurship Centers. The study adopts an empirical web-based content analysis of ten entrepreneurship centers in European Universities from seven countries, analyzing 105 curricular and extra-curricular entrepreneurship education programs. This method allows researchers to address generalization bias and to effectuate a cross-case comparison, thus revealing more common patterns regarding the phenomenon. Findings reveal some common pillars of EE as developed within the Entrepreneurship centers in terms of five key dimensions: target audience, learning objectives, entrepreneurship contents, learning pedagogies and stakeholders' engagement. This analysis provides the basis to introduce a process-based framework for entrepreneurial mindset creation in EE that is organized around four main phases: inspiration, engagement, exploitation and sustainment. The process-based model of EE supports entrepreneurship centers in designing learning initiatives that are aimed to inspire students at all levels of education, young entrepreneurs and start-uppers and scientists in their need to be equipped with an entrepreneurial mindset for technology entrepreneurship. The originality of the paper stands on the "process-based" framework that is proposed that serves as an interactive pathway that dynamically combines the phases toward entrepreneurial venture creation, the entrepreneurial competence level, the entrepreneurial learning strategies and collaboration with the University's stakeholders' network toward the achievement of the competence goal.
\end{abstract}

Keywords: entrepreneurship center; entrepreneurial mindset; entrepreneurship education; entrepreneurial learning; process-based framework

\section{Introduction}

In the past couple of decades, entrepreneurship education has increased in importance and interest amongst academics and business people [1-5]. The extant studies have highlighted the different aspects and impact of entrepreneurship education for sustainable development, individual growth, for propensity and intention for entrepreneurship and increased societal resilience [6-8]. Several researchers have focused on delineation of the differences that exist across countries and educational institutions in terms of objectives, target audiences, format and pedagogical approaches for developing entrepreneurial mindset [9] in University students. 
However, while EE (Entrepreneurship Education) has mainly been a priority for business schools, recently it has emerged as a relevant aspect to be created at all levels of education and for different disciplines. Specifically, in the wake of the rapid development of new technologies, an expansion of EE to other disciplines and departments are seen (e.g., science and technology) as crucial for developing skills, competencies and mindsets that are required for launching and developing high-growth, technology-based businesses [10]. This led to the flourishing in the academic community of the significant role of EE through a large number of initiatives, aimed to promote more entrepreneurial mindset in the field of technology entrepreneurship [11-14].

The notion of technology entrepreneurship is not new, and it was first addressed by Schumpeter [15] as the ability to respond to the creative processes of change [16,17], therefore contributing to economic and technological development [18]. Adopting a working interpretation, technology entrepreneurship can be understood as the capacity, competence and attitude to transform new ideas, technologies and inventions into commercially viable products and services to create economic and social value through innovative business models [19-21]. In today's business landscape, this notion has fundamental relevance and there is a need to address it in education, teaching and learning as a key competence to be developed by highly skilled human capital [22-24].

In this light, it is important to acknowledge the entrepreneurial mindset as a fundamental antecedent of technology entrepreneurship. The entrepreneurial mindset represents the competence of helping the members of society, students at all levels of education, young entrepreneurs and start-uppers to be creative and confident in whatever they undertake in order to cope with business uncertainty, ambiguity and complexity [25]. Students at all levels of education, young entrepreneurs and start-uppers need to be equipped with an entrepreneurial mindset, which is defined by five constituent elements: (1) the capacity to think creatively, strategically, analytically and reflectively, (2) confidence in one's abilities, (3) the ability to collaborate, (4) well-developed communication skills and (5) an understanding of the current business context [26]. Creating entrepreneurial mindset is essential for sustainable development [27]. The term sustainable entrepreneurship is often used to recall social entrepreneurship, ecopreneurship or intrapreneurship (e.g., sustainable innovations) [27]. This is a focal point for the promotion of entrepreneurship awareness [28] in influencing the students' behavior [29], in shaping an entrepreneurial perspective and spirit [1] (p. 577) and, finally, in increasing the potential to undertake startups and plan their growth strategies. Additionally, in recent years, some Higher Education Institutions (HEIs) have established dedicated Entrepreneurship Centers with the aim to support a broad spectrum of learning and research initiatives, providing funding for various educational programs as well as supporting social community development [30,31]. In addition, the literature points out that entrepreneurship centers have a focal position in stimulating enterprise and entrepreneurship activities within HEIs [32,33]. Nevertheless, even though their important role has been largely acknowledged, there is a lack of investigation related to how entrepreneurship centers organize their education actions in order to develop highly skilled human capital with an entrepreneurial mindset for technology entrepreneurship [34].

As [35] argues, the development of entrepreneurial competencies is associated with a series of challenges that are related to the clarification of "What", "Why", "When" and "How" to effectively create more entrepreneurial people in practice. Similarly, EE pose different challenges to the Entrepreneurship Centers' strategy and processes $[23,36]$. Therefore, more research is needed for better opening the "Black box" of the development of entrepreneurial mindset over time to understand "What" is intended with EE (personal development, mindset, skills and abilities etc.); “Why" EE can be relevant (objectives, reasons of entrepreneurial education, expected impacts and outputs); "When" to infuse entrepreneurship for EE audience (target groups, contents related to diversified target groups) and "How" to effectively create more entrepreneurial people in practice (defining learning strategies, content, pedagogy etc.) in entrepreneurship centers.

With the aim to cover this gap, this paper seeks to provide insights on what, why, when and how entrepreneurship centers realize EE in practice and on the identification of the common traits 
of a possible standardized approach to EE [5]. This is achieved through a comparable analysis of 10 European Entrepreneurship centers by examining five key dimensions of the learning initiatives analysed: target audience, learning objectives, entrepreneurship contents, learning pedagogies and stakeholders' engagement. The results obtained provide the basis for proposing a process-based framework to create Technology entrepreneurial mindset in practice by allowing participants to gradually change applied and learning outcomes as they progress in the educational path [35].

The paper is structured as follows: Section 2 highlights the paradigm shifts in EE; Section 3 describes the research method; Section 4 presents the main findings; and Section 5 proposes a process-based framework for technology entrepreneurial mindset creation. Finally, in the conclusion section, the challenges faced by entrepreneurship centers to develop an entrepreneurial mindset for technology entrepreneurship are discussed.

\section{Entrepreneurship Centers and Entrepreneurship Education (EE)}

Within the context of entrepreneurial universities, it is accepted that students should be exposed to entrepreneurial learning that encourages their inclinations and intentions to act enterprising and/or entrepreneurially [30]. In accordance with [37], there is a growing trend of HEIs to institutionalize entrepreneurship education by creating dedicated infrastructures and centers with the aim of moving beyond individual initiative and realizing the progressive accumulation of knowledge for entrepreneurial learning [38]. In addition, there is a tendency to move entrepreneurship education outside the business school as an effective way to influence the entire university [39] and to impact engineering, computer science and life sciences students who are generally more inclined to produce innovations [40]. The expansion of entrepreneurship education beyond business schools [3] to involve other discipline's departments may pose additional challenges to entrepreneurship education strategy and processes [23,41]. In this context, entrepreneurship centers play an important role both directly, by promoting their own programs and activities and indirectly, by undertaking joint programs/activities with other faculties and departments in order to develop enterprise and entrepreneurship activities [30].

\subsection{The Educational Role of Entrepreneurship Centers}

The most important priority for the entrepreneurship centers is the development of entrepreneurship curricula followed by the actual delivery of specific modules and programs [30]. It is argued that the majority of entrepreneurship centers should have an overall higher educational institution strategy that guides their activities [30]. The positioning of entrepreneurship centers within HEIs' structure varies significantly. For example, some are located within business schools, others function independently from faculties, whilst some are located in career advice services [42]. The location is linked to the HEIs' strategy. However, it seems that major attention is focused on the development of an entrepreneurship center that is interdisciplinary and accessible by all faculties within HEIs from Humanities to biology, engineering, business etc. [30].

Independently from the typology, the entrepreneurship centers integrate their curriculum and extra-curriculum activities with the development of a number of initiatives that are aimed to reach the external campus community in order to gain benefits from the participation and engagement of all the stakeholders belonging to the ecosystem in which the university is located [23]. This enables students to benefit from a wide variety of learning networking opportunities [43] as well as formal vs. informal learning practices [44,45]. The activities outside the classroom or extracurricular activities comprise mainly of activities related to: the design and launch of business, such as incubation initiatives, technology transfer, incubator/science parks; the development of Business and entrepreneurship, such as business consulting start-up and spin-off entrepreneurs-in-residence, venture capital funds, coaching start-ups; the exchange of Knowledge mainly in forums, workshops, summer schools, student conferences, student clubs; Business simulation and competition, such as venture camps, boot camps, business plan competitions [46]. 


\subsection{The Entrepreneurship Education (EE) Key Dimensions}

Previous studies have analyzed entrepreneurship education by focusing on components related to audiences, goals, learning strategies and content. For example, six key components distinguishing entrepreneurship education have been identified [47]: audiences, goals, pedagogies, content, educators and assessment. Similarly, Fayolle and Gailly [48] suggest that a framework for entrepreneurship education should be based on the following variables: objectives, audiences, content, assessment and pedagogies. These dimensions enable the identification of the most relevant aspects that entrepreneurship centers need to focus on in order to deliver EE. In addition, recent research highlighted the importance of the coordination of university programs for entrepreneurship with the wider entrepreneurial ecosystem [49]. The entrepreneurial ecosystem [50,51] has emerged as relevant for conducting and encouraging entrepreneurial mindset and behavior [52]. An entrepreneurial ecosystem for students has many dimensions. It includes entrepreneurship courses, incubators, accelerators, grants and business plan competitions [49]. Past studies have already underlined the role of stakeholders' collaboration in an entrepreneurial ecosystem [52]. As such, the dimension that is related to the stakeholder's involvement in creating a supportive environment for fostering and encouraging entrepreneurial attitude is a further dimension to take into account for the success of entrepreneurship education [52]. Therefore, it is possible to identify the following five main dimensions as key characteristics of the structuring and organization of EE: target audience, learning objectives, entrepreneurship contents, learning pedagogies and stakeholders' engagement. Such dimensions will allow the clarification of the main issues that are related to the [35] framework by specifying what is going to be achieved with EE (learning objectives); when to infuse different contents that are related to EE for the different target audiences considering their prior and acquired knowledge (target audience and entrepreneurship content), how different learning approaches and the interaction with outside stakeholders can stem the entrepreneurship mindset (learning pedagogies and stakeholder's engagement). Each component is presented in detail below.

Target audience-Since entrepreneurship is an intra-disciplinary as well as a trans-disciplinary process, it can be embedded into the curriculum of different disciplinary contexts, e.g., sciences, engineering, humanities and arts [53]. As such, in recent years, different entrepreneurship education initiatives have emerged in North American, Canadian and European universities, with the purpose to create entrepreneurial mindsets among non-business students in vocational disciplines like engineering, science and biology $[2,54]$. Recently, the development of entrepreneurship centers has further enlarged the target groups, also extending the learning initiatives from students to a wide variety of participants including managers, former entrepreneurs, young entrepreneurs and citizens and scientists in order to support lifelong learning for high-technology industries [55].

Learning objectives-The learning objectives of EE are wide and include: creating wide awareness about entrepreneurship, developing capacities throughout the university, developing self-efficacy (know-how, confidence and intention) to start a business or self-employment, supporting current start-ups, creating an understanding of the life-world of work and directly supporting the transition to employment in SMEs [56].

Defining the purpose of entrepreneurship education means distinguishing between the "wide" and the "narrow" definitions of entrepreneurship [35]. The programs intended to create creativity, self-reliance, personal development, initiative taking, action orientation and entrepreneurial mindset can be interpreted as "awareness education" or "educating about entrepreneurship" [57,58]. On the other hand, the programs related to the identification of opportunities for business development, venture creation and growth, in other words becoming an entrepreneur [48], can be labeled as "start-up education" [58] or "educating for entrepreneurship" [57]. Lastly, initiatives that focus on small business survival and progress are also emerging with the intent to provide the necessary abilities through entrepreneurial methodologies. They are known as "educating through entrepreneurship" or "growth education" [57]. 
Entrepreneurship contents-Educational programs show a wide variation in contents especially when considering programs that are devoted to non-business students [28]. The contents for non-business students that are related to entrepreneurship include subjects related to the comprehension of the business development process (ranging from start-up to growth and internationalization); general approaches for business management and entrepreneurial organizations' design in different contexts; the evaluation of business opportunities in different industries; comprehension of entrepreneurial management in different contexts. The basic idea is that students and participants should learn how to manage, grow and venture a business [46,57], not just how to start one. In a broad sense, [59] this means highlighting the existence of a gap between what is taught in entrepreneurship and what entrepreneurs do.

Learning Pedagogy-This includes educating individuals about the types of problems that are tackled by entrepreneurs [35] through the shift from traditional learning pedagogies, such as lectures and business cases, toward new pedagogies consisting of problem-based learning [28]. Different types of audiences (self-employed, new business starters, would-be entrepreneurs, high-growth entrepreneurs, students and so on) and, notably, in the context of university, undergraduate and graduate students of business administration and other disciplines (like engineering and sciences) have their own specificities in terms of education, background, learning styles and needs $[47,48]$. Therefore, it is essential for the entrepreneurship education to shift entrepreneurial learning pedagogies toward action-oriented learning, as well as creativity and reflections toward practicing enterprises through real processes [60]. Some authors suggest that the focus should be on the "venture creation approach" [61] or venturing projects that are real, intensive, interdisciplinary, iterative and hands-on [62].

Stakeholders' engagement-Collaboration with the university's external world is a crucial feature of entrepreneurial education [63]. The most developed systems for an effective collaboration between educational institutions and the external world seem to reflect the properties of the "triple-helix model" [64], taking the form of Industry-University-Business collaborations. Consequently, Universities should trigger collaborative links with a multiplicity of stakeholders including not only industry and other educational institutions, however also the wider learning communities within the civil society as well as other regional entrepreneurs [65-67] that belong to the wider university's entrepreneurial ecosystem [68].

Despite the above fundamental common aspects characterizing EE, it is important to point out that it is a very heterogeneous domain of practice which is characterized by bespoken typologies and taxonomies [28]. Although the role and relevance of entrepreneurship education are growing [3], there are few empirical investigations that are aimed at understanding the contribution that entrepreneurship centers can provide for the development of entrepreneurial mindset for technology entrepreneurship. Furthermore, past studies have focused on specific variables of EE, particularly single courses examination, while few studies have considered the whole learning process and curriculum contents of the entrepreneurial education initiatives. In addition, acknowledging that technology entrepreneurship plays an instrumental role in creating favorable environments for entrepreneurship cultural development $[57,69]$, the focus on EE becomes more prominent. Therefore, it is assumed that the entrepreneurship centers represent an appropriate level of analysis for the investigation of the approaches that are adopted by HEIs to develop entrepreneurship education [70].

\section{Research Method}

Framed in the above premises, the key research questions of this study are: Which are the key pillars that shape EE within Entrepreneurship Centers that are devoted to different target students? How do Entrepreneurship Centers structure these pillars for developing entrepreneurial competencies and mindset for technology entrepreneurship?

The investigation of these research questions was carried out by adopting a web-based content analysis [71]. The analysis has considered entrepreneurship centers that were chosen following criteria that was proposed in previous studies [72-74]: born and rooted in entrepreneurial universities [75,76]; 
located in regions characterized by higher levels of innovation (according to the Global Innovation Index -GII 2015- [77]; promoting an entrepreneurial culture by strategic actions; focused on developing an entrepreneurial mindset for technology entrepreneurship even if in some cases they are pure business school offering specialized programs that are focused on different typologies of technologies; offering diversified curricular and extracurricular initiatives for a wide target group of participants (students, scientists, entrepreneurs etc.). The study has considered 10 representative centers located within countries that are ranked at the top of the Global Innovation Index (GII 2015) [77]. The content analysis techniques have been defined as "a research technique for making replicable and valid inferences from data to their context" [78]. The main advantages that are related to the use of this technique include [78]: being unobtrusive; unstructured; context sensitive and able to cope with a large quantity of data; being able to examine the artefact (e.g., text, images) of communication itself and not the individual directly.

As [71] proposed, after formulating the research questions and selecting the sample, the content analysis continued with three other phases, consisting of:

Phase 1. Definition of categories for coding. In order to provide comparable cases for the entrepreneurship centers, we proceeded with the coding of the variables and items to analyse. According to the analysed literature, the main dimensions considered consist of: target audience, learning objectives, entrepreneurship contents, learning pedagogies and stakeholders' engagement.

Phase 2. Collection of the contents for coding and checking the coding reliability. For each center, all of the diverse initiatives that were put in place were scrutinized by distinguishing curricular and extra-curricular activities focusing on: Business Launch \& Development; Knowledge exchange; Business Simulation \& Competition [46]. In total, 105 learning initiatives were analyzed in the time period of September 2015-January 2016. With the aim to triangulate the findings and enhance the study reliability and validity, several data sources were used for gathering the information [78]. Data sources are listed in Table 1.

Table 1. Data sources.

\begin{tabular}{ll}
\hline \multicolumn{1}{c}{ Data Sources } & \multicolumn{1}{c}{ Description } \\
\hline Web site & $\begin{array}{l}\text { Contents and information from } 10 \text { web sites of the } \\
\text { entrepreneurship centers were analyzed in the period March } \\
\text { 2016-June 2016. }\end{array}$ \\
\hline \multirow{2}{*}{ Initiative programs and Brochures } & $\begin{array}{l}\text { In total, } 105 \text { initiatives were extracted and their programs and } \\
\text { brochures were scrutinized to collect in depth information } \\
\text { related to: target audience, learning objectives, entrepreneurship } \\
\text { contents, learning pedagogy and stakeholders' engagement. }\end{array}$ \\
\hline \multirow{2}{*}{ News, press } & $\begin{array}{l}\text { News on the web was scrutinized to collect and identify new } \\
\text { sources of data mainly about the centers' mission and their } \\
\text { learning initiatives. }\end{array}$ \\
\hline \multirow{2}{*}{ Facebook } & $\begin{array}{l}\text { The Facebook page of centers (6 out of 10 had dedicated } \\
\text { Facebook page: DELFT, INSEAD, TUM, COVENTRY, } \\
\text { SANTANDER INTERNATIONAL ENTREPRENEURSHIP } \\
\text { CENTRE) were considered to analyze the initiatives and } \\
\text { achievements performed by them. }\end{array}$ \\
\hline Ynterviews & $\begin{array}{l}\text { You tube interviews were scrutinized to obtain more insights on } \\
\text { the mission and strategies of the centers. The interviews of four } \\
\text { directors of centers were analyzed and in the other cases, } \\
\text { we found two interviews of chairs and professors of the centers. }\end{array}$ \\
\hline
\end{tabular}

Phase 3. Analysis and interpretation of the data that were collected. In order to reveal relevant features characterizing the entrepreneurship centers, each source was analyzed through the use of a content analysis approach [78]. For each entrepreneurship center and learning initiative offered by them (105 curricular and extra-curricular initiatives), the coding of contents was performed by 
adopting the mentioned categories and all of the data that were extracted were recorded in an Excel file. Data analysis was based on an in-depth cross-case analysis that was carried out through a graphic display. The results of the data analysis were validated through interviews with the directors of the selected centers. Finally, data clustering was performed to derive the "common pillars", distinguishing the development of entrepreneurial mindset for technology entrepreneurship.

\section{Research Findings}

In this section, a description of the main features and characteristics of the analyzed entrepreneurship centers is provided along with the detailed findings resulting from the analysis of the analysed learning initiatives. Then, a process-based framework to design and develop a learning program for entrepreneurial mindset development for technology entrepreneurship is proposed.

\subsection{An Analysis of Entrepreneurship Centers}

In order to identify archetypal benchmarks that are useful to extract insights about the approaches for developing entrepreneurship mindset in EE programs, 10 key representative case examples were analysed. Table 2 provides a summary description of the selected sample of analysis. All entrepreneurship centers are committed to achieving a common mission as follows: to be highly focused on boosting and accelerating the technology oriented entrepreneurial attitude, ambitions and mindset through a set of different programs and initiatives. With this aim, the set of curricular and extracurricular learning initiatives span out from education and research to incubation programs, workshops and competition. The curricular activities mostly are aimed at disseminating an entrepreneurial culture and mindset as well as encouraging the development of enterprise aptitudes (such as creativity, innovative thinking, entrepreneurial mindset and so on), while the extra-curricular learning activities are complementary and primarily focused on the development of practical experience for technology entrepreneurship. The high variety of extra-curricular activities reflects the wide target audience and the diversified set of needs and competencies to be satisfied with the EE. In fact, the target audience tends to be extensive and multidisciplinary, spanning from undergraduate, graduate and postgraduate students to executives and managers, as well as entrepreneurs or those who already have a business idea.

The nature of the impact of the entrepreneurship centers is considered an important performance aspect to account and it is generally measured by using a set of indicators, including new start-ups created; the number of entrepreneurs sustained; the number of individuals who have created their own endeavors; the extent of the network created around the center, as well as the several recognition and awards that they have been acknowledged for in the European and global scenario. 
Table 2. The European Entrepreneurship centers sample.

\begin{tabular}{|c|c|c|c|c|}
\hline Entrepreneurship Center & Mission of the Center & Target & Entrepreneurship Initiatives & Achievements \\
\hline $\begin{array}{l}\text { Delft Center of } \\
\text { Entrepreneurship, } \\
\text { NETHERLAND }\end{array}$ & $\begin{array}{l}\text { Encourage students and researchers to } \\
\text { become entrepreneurs and to engage in } \\
\text { entrepreneurial activities through four } \\
\text { pillars: INSPIRATION, ACTIVATION, } \\
\text { EDUCATION, REALIZATION. }\end{array}$ & $\begin{array}{l}\text { Students } \\
\text { Executives } \\
\text { Scientists } \\
\text { Entrepreneurs } \\
\text { Companies }\end{array}$ & $\begin{array}{l}\text { Education and Research } \\
\text { Incubation programme and Support } \\
\text { Workshop, Symposium, Forum } \\
\text { Competition. }\end{array}$ & 151 start-ups. \\
\hline $\begin{array}{l}\text { Netherlands Institute for } \\
\text { Knowledge Intensive } \\
\text { Entrepreneurship (NIKOS), } \\
\text { NETHERLAND }\end{array}$ & $\begin{array}{l}\text { Give education and research about } \\
\text { entrepreneurship as well as } \\
\text { consultancy, training and business } \\
\text { development support. }\end{array}$ & $\begin{array}{l}\text { Students } \\
\text { Entrepreneurs } \\
\text { Businesses }\end{array}$ & $\begin{array}{l}\text { Education and Research } \\
\text { Consultancy \& training and business } \\
\text { development support } \\
\text { VentureLab \& Symposium } \\
\text { Incubation }\end{array}$ & $\begin{array}{l}450 \text { entrepreneurs, } \\
300 \text { firms supported. }\end{array}$ \\
\hline $\begin{array}{l}\text { INSEAD - International Center } \\
\text { for Entrepreneurship (ICE), } \\
\text { FRANCE }\end{array}$ & $\begin{array}{l}\text { Accelerate the entrepreneurial } \\
\text { ambitions of students and turn } \\
\text { INSEAD into a catalyst for } \\
\text { entrepreneurship initiatives, providing } \\
\text { inspiration, driving team formation } \\
\text { and facilitating venture development. }\end{array}$ & $\begin{array}{l}\text { Students } \\
\text { Alumni (start uppers, } \\
\text { entrepreneurs, etc.) }\end{array}$ & $\begin{array}{l}\text { Education and Research } \\
\text { Entrepreneurship Education Fund } \\
\text { BootsCamp, VentureCompetition } \\
\text { Forum, Entrepreneurs in Residence }\end{array}$ & $\begin{array}{l}53 \% \text { of alumni engage in } \\
\text { entrepreneurial activities during their } \\
\text { career. }\end{array}$ \\
\hline EMLYON Incubator, FRANCE & $\begin{array}{l}\text { Provide assistance from the outset of } \\
\text { entrepreneurship process, giving a } \\
\text { robust support structure. }\end{array}$ & $\begin{array}{l}\text { Executives } \\
\text { Researchers } \\
\text { Students } \\
\text { Entrepreneurs }\end{array}$ & $\begin{array}{l}\text { Academic Entrepreneurship Course } \\
\text { and Programme } \\
\text { Pre-incubation Programme: } \\
\text { Entrepreneurs in the City, start-up } \\
\text { programme } \\
\text { Incubation Initiatives: Boost } \\
\text { programme, Mentorship } \\
\text { Executive education for growth }\end{array}$ & $\begin{array}{l}1.350 \text { entrepreneurs supported, } \\
950 \text { companies set up or taken over, } \\
10 \text { of which are stock-market listed } \\
90 \% \text { five-year survival rate, } \\
11,000 \text { direct jobs created. }\end{array}$ \\
\hline $\begin{array}{l}\text { Center for Entrepreneurial } \\
\text { Learning (CfEL), UK }\end{array}$ & $\begin{array}{l}\text { Spread the spirit of enterprise by } \\
\text { providing educational activities to } \\
\text { inspire and build skills in the practice } \\
\text { of entrepreneurship. }\end{array}$ & $\begin{array}{l}\text { Aspiring } \\
\text { entrepreneurs } \\
\text { (students, PhDs, etc.) } \\
\text { Entrepreneurs } \\
\text { Innovators } \\
\end{array}$ & $\begin{array}{l}\text { Entrepreneurship Course and } \\
\text { Lectures } \\
\text { Training Programme } \\
\text { Business Simulation and Competition }\end{array}$ & $\begin{array}{l}\text { More than } 200 \text { business ventures } \\
\text { created. }\end{array}$ \\
\hline $\begin{array}{l}\text { Center for Entrepreneurship, } \\
\text { TUM Munich, GERMANY }\end{array}$ & $\begin{array}{l}\text { Inspire the next generation of } \\
\text { entrepreneurs through unique, } \\
\text { integrated instruction to identify the } \\
\text { challenges and develop solutions. }\end{array}$ & $\begin{array}{l}\text { Enterprise } \\
\text { Students } \\
\text { Researchers }\end{array}$ & $\begin{array}{l}\text { Education and Research } \\
\text { Service for Entrepreneurs: Start-up } \\
\text { program and executive training } \\
\text { Start-up Fund } \\
\text { Summer/Spring School } \\
\text { Business Simulation and Game }\end{array}$ & $\begin{array}{l}\text { More than } 700 \text { companies. Center for } \\
\text { Innovation and Business Creation } \\
\text { (per year): } 50 \text { Start-ups, } \\
1000 \text { Participants, } 10 \text { Industry } \\
\text { Partners. }\end{array}$ \\
\hline
\end{tabular}


Table 2. Cont

\begin{tabular}{|c|c|c|c|c|}
\hline $\begin{array}{l}\text { Coventry University } \\
\text { Centre for Transformational } \\
\text { Entrepreneurship, Coventry, UK }\end{array}$ & $\begin{array}{l}\text { Support sustainable socioeconomic } \\
\text { transformation through systemic } \\
\text { approaches to entrepreneurship in } \\
\text { communities nationally and } \\
\text { internationally. }\end{array}$ & $\begin{array}{l}\text { Graduates, potential } \\
\text { entrepreneurs, } \\
\text { businesses employees } \\
\text { (educators) }\end{array}$ & $\begin{array}{l}\text { Entrepreneurship Course and } \\
\text { Lectures } \\
\text { Elective modules } \\
\text { Workshops }\end{array}$ & Not available. \\
\hline $\begin{array}{l}\text { ITU Business Development } \\
\text { A/S, IT University of } \\
\text { Copenhagen, DENMARK }\end{array}$ & $\begin{array}{l}\text { Start-up accelerator for entrepreneurs } \\
\text { affiliated with the university. }\end{array}$ & $\begin{array}{l}\text { StudentStart-up } \\
\text { Researchers } \\
\text { Business }\end{array}$ & $\begin{array}{l}\text { Business Lunch Initiatives } \\
\text { Technology transfer activities } \\
\text { VentureCup Competition }\end{array}$ & More than 100 companies. \\
\hline $\begin{array}{l}\text { Santander International } \\
\text { Entrepreneurship Centre, } \\
\text { University of Cantabria (SPAIN) }\end{array}$ & $\begin{array}{l}\text { Entrepreneurial culture and seek to } \\
\text { support innovation in existing business } \\
\text { models and the creation of start-ups } \\
\text { with the sole purpose of contributing to } \\
\text { economic and social progress. }\end{array}$ & $\begin{array}{l}\text { Students } \\
\text { Businesses } \\
\text { Entrepreneurs }\end{array}$ & $\begin{array}{l}\text { Education } \\
\text { Students-entrepreneurs exchange } \\
\text { Workshops } \\
\text { Symposia } \\
\text { Advanced learning }\end{array}$ & Not available. \\
\hline $\begin{array}{l}\text { Centre for Engaged Education } \\
\text { through Entrepreneurship, } \\
\text { NORWAY }\end{array}$ & $\begin{array}{l}\text { Combine, develop and disseminate } \\
\text { action-based learning, } \\
\text { student-to-student learning, } \\
\text { collaborative skills, rapid prototyping } \\
\text { and student engagement. }\end{array}$ & $\begin{array}{l}\text { Students } \\
\text { Businesses }\end{array}$ & $\begin{array}{l}\text { Education } \\
\text { Mentorship program } \\
\text { Support } \\
\text { Research }\end{array}$ & $\begin{array}{l}50 \text { percent of the students work in } \\
\text { their own business after graduation. }\end{array}$ \\
\hline
\end{tabular}

Source: Adapted from "anonymous for review purpose". 


\subsection{Key Pillars Characterizing Entrepreneurship Education in the Entrepreneurship Centers}

The cross-case analysis of the 105 learning initiatives revealed a pattern regarding the main approaches that were adopted by the 10 entrepreneurship centers for creating entrepreneurial mindsets for technology entrepreneurship and allowed us to provide an answer to the first research question. The analysis revealed useful insights regarding the main pillars of EE: target audience, learning objectives, entrepreneurship contents, learning pedagogy and stakeholders' engagement, as listed in the columns of Table 3.

Data analysis of the learning initiatives allowed us to cluster the contents of each dimension into four main groups (rows in Table 3) corresponding to the general aim of the learning initiatives. These clusters range from the learning initiatives that are aimed to guide participants from the inspiration and creation of awareness to the creation and design of a business idea, to the practical capabilities for creating workable competence for the creation and sustainment of new ventures, passing from the turning of an idea in business for technology entrepreneurship.

The wide range of learning curricular and extracurricular initiatives that have been developed by centers target both students and professionals with different levels of knowledge, awareness and recognition in relation to entrepreneurship competencies, attitudes and capabilities to acquire [79]. Due to the different entrepreneurship learning needs, the learning activities are focused on diverse areas of competence, ranging from awareness creation and inspiration to the development of more action-based capabilities for the entrepreneurial process as well as to the capabilities and competencies for the acceleration and growth of enterprise ventures $[68,80]$. The learning activities directed towards the target audience with a low level of entrepreneurship understanding focus mainly on the creation of awareness as well as sensitizing, inspiring and providing participants with first-hand knowledge of entrepreneurship aspects. Instead, for those target audiences that are eager to find out, develop their own ideas and create ventures, the learning initiatives seek to achieve goals that are related to creating action-based and practical capabilities for designing, developing, implementing and sustaining business ideas and new ventures [39].

The in-depth analysis of programs and initiatives of the entrepreneurship centers has identified a multitude and multidisciplinary set of entrepreneurship contents. For those initiatives that are oriented toward creating an entrepreneurial mindset and awareness, the main programs and initiatives cover scenario understanding, fundamentals and principles of technology entrepreneurship and opportunity recognition in order to provide a general understanding of how to identify, recognize emerging opportunities and trends and how to stem creative thinking for new solutions.

Instead, more specialized contents that are related to design and ideation of technological innovations, launching and positioning a new venture, creativity and design are aimed at providing target groups with hands-on knowledge for developing a new venture. In addition, contents that are related to how to grow and sustain a new venture are delivered specifically with the aim to develop capabilities and the mindset to sustain and accelerate sustainable growth by continuously seeking innovation and creativity. 
Table 3. The "common pillars" of the Entrepreneurship Education in the entrepreneurship centers.

\begin{tabular}{|c|c|c|c|c|c|}
\hline \multirow[b]{2}{*}{ AIM } & \multicolumn{5}{|c|}{ Entrepreneurship Education Dimensions } \\
\hline & Target Audience & Learning Objectives & Entrepreneurship Contents & Learning Pedagogy & $\begin{array}{l}\text { Stakeholders' } \\
\text { Engagement }\end{array}$ \\
\hline $\begin{array}{l}\text { Inspire and create } \\
\text { awareness }\end{array}$ & $\begin{array}{l}\text { Low profile of knowledge } \\
\text { on entrepreneurship } \\
\text { (bachelor, masters } \\
\text { students, PhD students). }\end{array}$ & $\begin{array}{l}\text { Understand, sense, } \\
\text { inspire, analyze, become } \\
\text { aware, discuss/reflect, } \\
\text { acquire knowledge on } \\
\text { technology } \\
\text { entrepreneurship. }\end{array}$ & $\begin{array}{l}\text { Fundamentals of Technology } \\
\text { entrepreneurship, Intrapreneurship, } \\
\text { Entrepreneurial Thinking, Entrepreneurs } \\
\text { and Democracy, Social of } \\
\text { Entrepreneurship. }\end{array}$ & $\begin{array}{l}\text { Lectures/seminars/Teamwork } \\
\text { in-class exercises, reflections } \\
\text { and discussions/debates and } \\
\text { inspirational } \\
\text { seminars/Entrepreneurs talk } \\
\text { Entrepreneur-in-Residence } \\
\text { Inspirational lectures. }\end{array}$ & $\begin{array}{l}\text { Starting to enter into the } \\
\text { entrepreneurship } \\
\text { ecosystem by inviting } \\
\text { entrepreneurs to take a } \\
\text { seminar in class for } \\
\text { creating awareness. }\end{array}$ \\
\hline $\begin{array}{l}\text { Idea generation } \\
\text { and design }\end{array}$ & $\begin{array}{l}\text { Inspired and awarded } \\
\text { students regarding the } \\
\text { opportunities of } \\
\text { entrepreneurship } \\
\text { (students, businesses, } \\
\text { researchers). }\end{array}$ & $\begin{array}{l}\text { Recognize, explore, } \\
\text { analyze opportunities and } \\
\text { develop knowledge, skills, } \\
\text { competencies, capabilities } \\
\text { for the entrepreneurial } \\
\text { process "technology } \\
\text { based". }\end{array}$ & $\begin{array}{l}\text { Innovative Entrepreneurship; Idea } \\
\text { generation } \\
\text { Trendspotting and Future Thinking; } \\
\text { Business Model, Design, Plan; Project } \\
\text { and research methods for } \\
\text { entrepreneurship; Entrepreneurial } \\
\text { Marketing; Entrepreneurship in the Life } \\
\text { Sciences } \\
\text { Technology Entrepreneurship Lab; } \\
\text { Entrepreneurial Finance and Law. }\end{array}$ & $\begin{array}{l}\text { Lectures, seminars, case } \\
\text { studies, problem based } \\
\text { learning, learning by } \\
\text { doing/ exercises, discussions } \\
\text { and case studies, business } \\
\text { plan competition, Business } \\
\text { trips start-up events. }\end{array}$ & $\begin{array}{l}\text { Events for Networking } \\
\text { creation } \\
\text { Visits to businesses } \\
\text { Visits to technological } \\
\text { parks and incubators. }\end{array}$ \\
\hline $\begin{array}{l}\text { Turn idea into } \\
\text { business }\end{array}$ & $\begin{array}{l}\text { Increased level of } \\
\text { knowledge, competencies, } \\
\text { awareness and } \\
\text { recognition of the } \\
\text { opportunities for } \\
\text { entrepreneurship } \\
\text { (students, businesses, } \\
\text { entrepreneurs, } \\
\text { researchers). }\end{array}$ & $\begin{array}{l}\text { Design, Apply, Build, } \\
\text { Launch, Develop, } \\
\text { Implement business ideas, } \\
\text { new ventures, new } \\
\text { business models for } \\
\text { technology intensive } \\
\text { businesses. }\end{array}$ & $\begin{array}{l}\text { Design of technological innovations; } \\
\text { Design and leadership; Strategy and } \\
\text { creativity; Creativity and Enterprising } \\
\text { Behavior; Creativity and enterprising } \\
\text { behavior; New Venture Creation. }\end{array}$ & $\begin{array}{l}\text { Action based } \\
\text { learning/Entrepreneurial } \\
\text { Project, Industrial visits/ } \\
\text { Incubation/Mentorship, } \\
\text { Pitching and Venture } \\
\text { Competition, hands-on } \\
\text { project work, practical } \\
\text { mentored sessions. }\end{array}$ & $\begin{array}{l}\text { Co-working in a project } \\
\text { based and action based } \\
\text { modality with different } \\
\text { businesses, banks, public } \\
\text { administration, } \\
\text { technology research } \\
\text { institution for creating } \\
\text { new ventures. }\end{array}$ \\
\hline Grow and sustain & $\begin{array}{l}\text { High level of knowledge, } \\
\text { competencies and } \\
\text { capabilities for venture } \\
\text { creation (entrepreneurs, } \\
\text { innovators, businesses). }\end{array}$ & $\begin{array}{l}\text { Accelerate, support, lead, } \\
\text { coach, counsel, take off, } \\
\text { innovate, grow, sustain } \\
\text { the venture "technology } \\
\text { intensive". }\end{array}$ & $\begin{array}{l}\text { Managing New Venture Growth; } \\
\text { Entrepreneurial Strategy; Crowdfunding } \\
\text { Take off-Growth; Innovation Service } \\
\text { Growth Programme; Development } \\
\text { companies } \\
\text { Advanced marketing, strategic } \\
\text { innovation, Intellectual Property Rights; } \\
\text { Business sustainability. }\end{array}$ & $\begin{array}{l}\text { Experiential learning, } \\
\text { Conferences } \\
\text { Workshops, Incubation } \\
\text { Services consulting, } \\
\text { professional coaching, } \\
\text { specialized seminars and } \\
\text { counselling. }\end{array}$ & $\begin{array}{l}\text { Entrepreneurship } \\
\text { ecosystem. }\end{array}$ \\
\hline
\end{tabular}


The learning pedagogies span out from traditional forms such as lectures, seminars, debates and inspirational lectures to more interactive, practice-based and experimental methods [43] (pp. 7). The type of learning approach adopted is highly related to the type of content delivered and the goals to be achieved. Learning methods that are adopted for creating general understanding and awareness are mainly traditionally bounded, consisting of lectures, case studies, seminars and so on. More generally, the centers promote the use of applied learning technologies and action learning in order to give participants the opportunity to develop personal knowledge by encouraging them to be innovative.

All centers pay great attention to the engagement of different stakeholders to attain valuable knowledge from external partners to support their activities by providing knowledge and resources [81]. The involvement can span from participation in meetings or lectures to the engagement in action-based learning strategies, such as direct involvement of the participants with businesses, entrepreneurial forums, participation and collaboration in creating new entrepreneurial initiatives, work placements, incubation, entrepreneurial networks, story-telling, coaching and mentoring.

\subsection{Discussion: A Process-Based Framework for Developing Entrepreneurial Mindset in Student Entrepreneurs}

The cross-case web-based data analysis revealed a remarkable pattern regarding the structuring of the main pillars that the centers adopt for developing entrepreneurial competencies for technology entrepreneurship.

As discussed above, there is a general orientation towards structuring entrepreneurial education and initiatives according to four main groups (as demonstrated by the rows in Table 3) that seek to guide and sustain different target profiles to move through a process of awareness and opportunity recognition to the creation of practical capabilities for creating workable concepts and allowing the growth of new ventures. Although centers do not explicitly refer to a structured process-based approach, they organize their activities and initiatives in accordance with a progression path with the aim to infuse entrepreneurship education in participants in accordance to their specific needs, prior knowledge and the competencies acquired so far, and align the learning pedagogy and stakeholder's involvement with the specific aim of the phase. This element provides some insights in relation to the question Why of the [35] framework and provides an answer to the second research question which is aimed to understand how entrepreneurship centers shape their EE programs.

Moreover, the interviews with directors of four centers confirmed the tendency to structure the learning initiatives according to a phase-based process and progression model that goes from recognizing or creating an opportunity for value creation; converting this opportunity into a workable concept; and capitalizing on the concept in a (growing) organization.

As such, following the contents of each dimension into four main groups in an integrated process-based framework is proposed. The framework consists of four phases of the learning path corresponding to the entrepreneurial stages (from inspiration to sustainment), the entrepreneurial competencies to be developed in people (from knowledge and awareness development to value creation for technology entrepreneurship), the learning objectives to be achieved (from the creation of entrepreneurial awareness to the capacity to create value with the new venture), the learning pedagogies (from traditional to action based), the stakeholder engagement (from lecture to joint projects with participants) and, finally, the entrepreneurship content (from fundamentals on technology entrepreneurship to specialized aspects on venture creation and growth) that characterize the typology of the learning initiatives (see Figure 1).

Therefore, the EE learning programs that are aimed to develop entrepreneurial mindset can be structured around the following phases corresponding to the entrepreneurial venture development stages:

INSPIRATION — this phase focuses on generating broad entrepreneurial AWARENESS connected to technology entrepreneurship as well as whole comprehensiveness and familiarity that are required for instigating and handling a technology-based entrepreneurial activity. 
ENGAGEMENT - this step is concentrated on creating in the target groups specific entrepreneurship capabilities, competencies and skills that are directed to examine, sense and perform upon new prospects and to take advantage of them in an entrepreneurial edge in an original and groundbreaking way.

EXPLOITATION-creating hands-on entrepreneurial capabilities constitutes the third stage of the process that is aimed to take advantage of opportunities that emerge by putting the participants in real-world conditions to solve specific problems by ideating, planning and managing new endeavors.

SUSTAINMENT-lastly, the fourth stage consists of providing the targets with techniques, instruments, resources, acquaintance and aptitudes to endure the growth and to be capable of producing entrepreneurial value through the new endeavor.

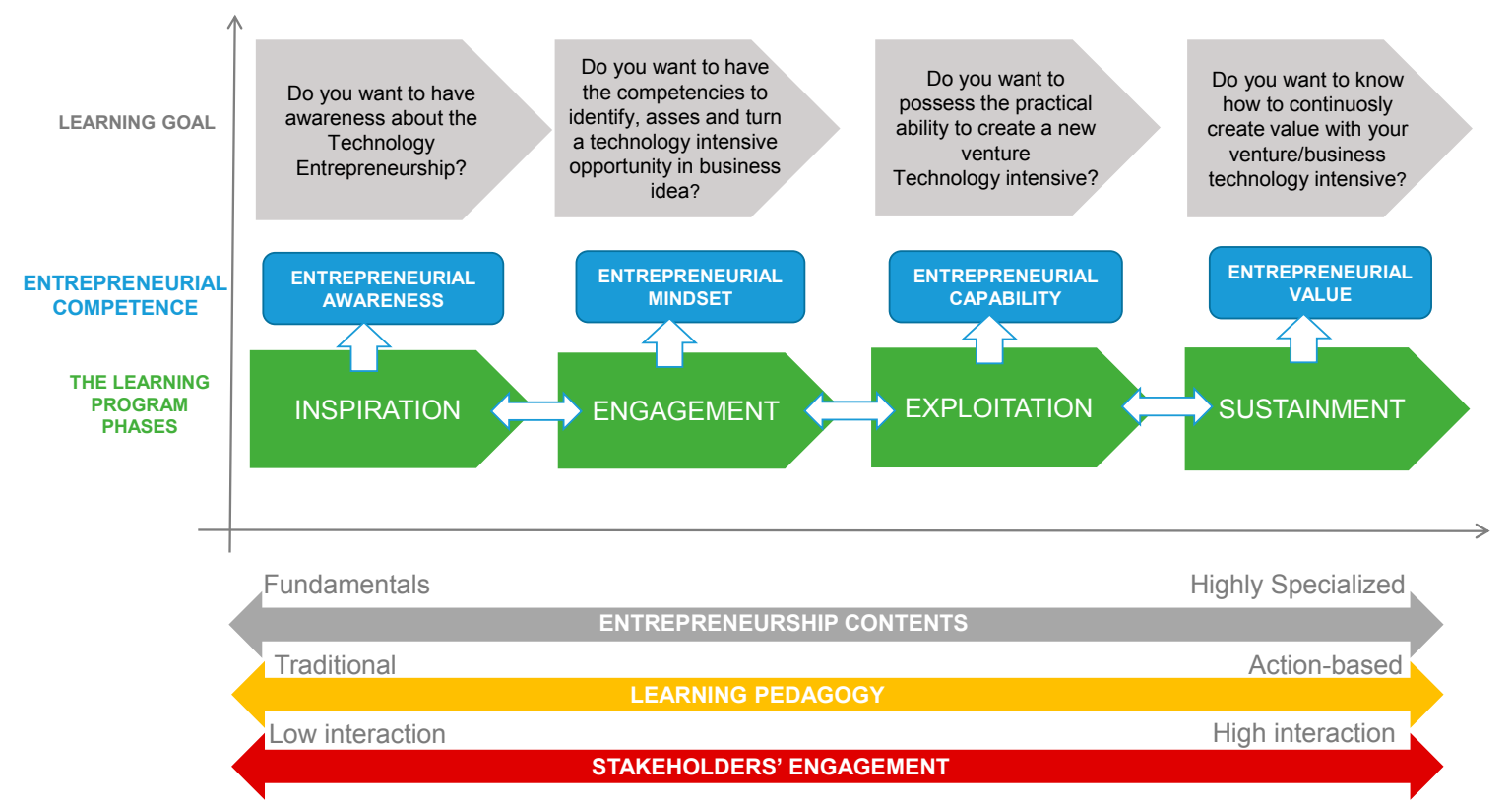

Figure 1. A process-based framework for entrepreneurial mindset development in EE (Entrepreneurship Education).

This framework yields some relevant insights into the "black box" of EE by providing interesting understanding of how, when and why participants engage in different phases of the model and which entrepreneurial competencies they seek to develop starting from the entrepreneurial awareness to entrepreneurial value.

First of all, it provides a novel approach to identify and put together some unifying characteristics of entrepreneurial education and allows us to correlate and structure the large variety of content, pedagogical tools and methods in relation to targets, goals and progression stage in the development of entrepreneurial mindset for technology entrepreneurship. This is coherent with the argument that the learning process in entrepreneurship education should focus on real-world experience, action and reflective processes to engage students in authentic learning [82] which should lead from entrepreneurial awareness of the inspiration and engagement phase to greater entrepreneurial capabilities of the exploitation phase. Furthermore, the conceptual framework allows us to identify different sets of learning processes that are coherent with the evolution of innovation capabilities in technology-based ventures that see the entrepreneurial learning as a dynamic process operating across multiple levels [83].

Secondly, it is a dynamic and evolutionary process that allows for a progression path that leads toward a gradual update of the main areas of competence that are essential for the development of a mindset and aptitude for entrepreneurship. This aligns with previous studies that have argued that an effective entrepreneurial process follows an evolutionary path in the time and effort [84]. It could be 
deliberated as a common scheme assumed by entrepreneurship centers for realizing entrepreneurial learning programs intended to form entrepreneurial awareness, mindsets and aptitudes for technology entrepreneurship [6]. This is in line with the evidence that different modes of learning have any influence on the different typologies of entrepreneurial knowledge that increase participants' ability to recognize and exploit new business opportunities [85].

Thirdly, the development of entrepreneurial mindset requires the activation of different types of activities and stages [86], and depending on industry sector and technology context, these activities can have very different competence requirements. The framework suggests that contents delivered for entrepreneurship follow an interdisciplinary approach [87] and a multitude of stakeholders are involved in the aim to engage entrepreneurs and business persons in the educational process [81]. However, independently, if attention is paid to new venture creation, intrapreneurship, corporate venturing or strategic entrepreneurship, there are common and specialized skill demands. Some industries, such as biotech, require a detailed understanding of venture capital and IPR, whereas the traditional entrepreneurial ventures entail basic business, financial and legal skills [88].

\section{Conclusions}

Entrepreneurship centers can play a bridging role in the fields of technology entrepreneurship, thus contributing to the Entrepreneurship Education (EE). Following the trend that entrepreneurship centers can achieve more if they do not belong to a specific faculty or department, it could be reasoned that such centers should be the guardians of the entrepreneurial ecosystem within HEIs [30] due to their contribution to the creation of human capital with an entrepreneurial mindset.

This paper sheds lights on the "black box" of "how, when, why and what" entrepreneurial mindset and competencies in the field of technology entrepreneurship are learned over time in the Entrepreneurship Centers. Moving from an empirical research web-based content analysis of 10 entrepreneurship centers in European Universities from seven countries, after analyzing 105 curricular and extra-curricular entrepreneurship education programs, findings reveal some common pillars of EE in terms of five key dimensions: target audience, learning objectives, entrepreneurship contents, learning pedagogies and stakeholders' engagement. This analysis provides the basis to introduce a process-based framework for entrepreneurial mindset creation in EE organized around four main phases: inspiration, engagement, exploitation and sustainment. This is a holistic framework of EE that is anchored at the intersection between the technology entrepreneurship and the entrepreneurship education stream of research and is coherent with the need to connect the macro-level (political policy) with the micro-level (student competencies need) by focusing on the meso-level (university/center education) [88]. The originality of the paper stands on the "process-based" framework proposed that serves as an interactive pathway that dynamically combines the phases toward entrepreneurial venture creation, the entrepreneurial competence level, the entrepreneurial learning strategies and collaboration with the University's stakeholders' network toward the achievement of the competence goal.

Implications for theory. From the theory point of view, this contributes to a clear identification of the strategic pillars of STTE for entrepreneurial mindset development. Accordingly, the entrepreneurship education learning initiatives targeted towards different participants' needs can be organized around a process-based framework that is composed of four entrepreneurial stages devoted to students, managers, entrepreneurs and academics, with specific requisites and objectives to be achieved [80]. These domains are interlinked and are structured in an evolutionary mode that seeks to guide the target groups along the path that best fits their prior knowledge/skills and objectives to attain, starting from a previous self-assessment.

These findings provide some useful guidelines on What, Why, When and How to effectively create technology entrepreneurship mindset by specifying the type of contents that fits different target groups and the most suitable learning strategies, as well as the extent and typology of the relationship with the external environment and stakeholders. Specifically, undergraduate and graduate 
students start their path toward entrepreneurial learning from the first stage (inspiration) with the aim to create mindfulness and inspiration. They then advance to other stages related to engagement and exploitation in order to develop more action-based aptitudes for the entrepreneurial process (sustainment). Alternatively, new entrepreneurs' participation is more concerned with exploitation and sustainment stages as they are more fascinated by learning with how to deal with variations, how to react innovatively to new contests and how to speed up and endure the growth of their endeavour over time. In the same way, the learning pedagogies and methodologies need to be arranged in strict relation to the level of familiarity, skills and competencies of the participants and by following a process-based archetypal. Suitable methodologies for developing compulsory practical skills and for instilling entrepreneurial mindset consists of the active involvement of participants in practical and experiential learning projects. Moreover, the involvement of a wide range of stakeholders' is realized according to a stage-based process that can be planned, highlighting clear differences in the learning strategies and outcomes of the involvement. Their involvement in the first stages (such as in the inspiration phase) is lower and is mainly confined to short meetings with entrepreneurs and inspirational lectures. As the participants move on along the pathway, their relationship with the ecosystem becomes tighter and stronger. In the final phases, the participants develop team work with a variety of stakeholders [48] to solve industry-based assignments [23] to suggest new collaborative innovative solutions through frequent meetings and discussions [28], thus guaranteeing that the curricula is linked with the industry.

Implications for practices. From a practical point of view, it is essential to start by recognizing that the entrepreneurship centers could support an "entrepreneurial journey" [44] by assisting the participants' conversion from university students to entrepreneurs on their journey from university to business through the implementation of entrepreneurship education initiatives.

Furthermore, the implications of this study also applies to sustainable entrepreneurship. Therefore, entrepreneurship centers can also target the sustainable entrepreneurs that seek to base their entrepreneurship activities in solving social or environmental problems with their entrepreneurial activities. Therefore, the entrepreneurship education initiatives can be conceived according to their specific social, ecological and economic development aims.

The framework entails several implications for practitioners: first of all, it makes available a dynamic pathway for entrepreneurial mindset creation by combining an interactive mode that is different to the learning variables in coherence with the entrepreneurial venture creation process. The framework also inspires the dissemination of an entrepreneurial mindset through the establishment of lifelong learning initiatives for different audiences belonging to the entrepreneurial ecosystem. In addition, it allows the arrangement of a wide range of curricular and extra-curricular activities to encourage the entrepreneurial mindset diffusion in the whole university. Finally, the framework offers important guiding principles for professors and directors of the centers for designing and developing educational programs to instill an entrepreneurial mindset and culture in the society.

Limitations and future research. Although a web-based content analysis of cases can be challenged for its limitation in relation to the generalizability of its result, adopting a falsifiability standpoint [89], we consider the framework valid to interpret and describe learning programs that are adopted by entrepreneurship centers in order to develop entrepreneurship mindset and competence for technology entrepreneurship. Although, we accept that each learning program will present specific and idiosyncratic features and traits, resulting from tailoring the four fundamental phases "inspiration, engagement, exploitation and sustainment" to the specific context and practical reality in which the learning initiatives and activities will take place. Therefore, we acknowledge that entrepreneurship learning programs are context-specific and strongly affected by the cultural and economic dimensions characterizing the entrepreneurial ecosystem in which they take place. The impact of context is rarely addressed in the entrepreneurship education literature [90,91]; the context clearly plays an important role in what is possible, achievable and appropriate in entrepreneurship education [92,93]. This would require relevant investigation. We call for further research investigating the translation of 
the framework into action as well as the understanding of how it can drive the design and assessment of learning programs of EE. Finally, further research should be aimed to complete the reliability of the analysis using other sources of evidence, such as other interviews with center directors.

Author Contributions: Supervision, Giuseppina Passiante; Writing—original draft, Valentina Ndou and Giustina Secundo; Writing—review \& editing, Giovanni Schiuma.

Funding: This research received no external funding.

Conflicts of Interest: The authors declare no conflict of interests.

\section{References}

1. Kuratko, D. The emergence of entrepreneurship education: Development, trends, and challenges. Entrep. Theory Pract. 2005, 29, 577-598. [CrossRef]

2. Katz, J.A. The chronology and intellectual trajectory of American entrepreneurship education: 1876-1999. J. Bus. Ventur. 2003, 18, 283-300. [CrossRef]

3. Katz, J.A. Fully Mature but Not Fully Legitimate: A Different Perspective on the State of Entrepreneurship Education. J. Small Bus. Manag. 2008, 46, 550-566. [CrossRef]

4. Nabi, G.; Liñán, F.; Fayolle, A.; Krueger, N.; Walmsley, A. The Impact of Entrepreneurship Education in higher Education: A Systematic Review and Research Agenda. Acad. Manag. Learn. Educ. 2016, 16, $277-299$. [CrossRef]

5. Jones, C.; Matlay, H. Understanding the heterogeneity of entrepreneurship education: Going beyond Gartner. Educ. Train. 2011, 53, 692-703. [CrossRef]

6. Bae, T.J.; Qian, S.; Miao, C.; Fiet, J.O. The Relationship Between Entrepreneurship Education and Entrepreneurial Intentions: A Meta-Analytic Review. Entrep. Theory Pract. 2014, 38, 217-254. [CrossRef]

7. Pittaway, L.; Cope, J. Simulating Entrepreneurial Learning: Integrating experiential and Collaborative Approaches to Learning. Manag. Learn. 2007, 38, 211-233. [CrossRef]

8. Fayolle, A.; Basso, O.; Tornikoski, E. Entrepreneurial Commitment and New Venture Creation: A Conceptual Exploration. In Handbook of Research on New Venture Creation; Hindle, K., Klyver, K., Eds.; Edward Elgar: Cheltenham, UK, 2011; pp. 160-182.

9. Fayolle, A.; Klandt, H. (Eds.) International Entrepreneurship Education: Issues and Newness; Edward Elgar Publishing: Cheltenham, UK, 2006.

10. Boocock, G.; Frank, R.; Warren, L. Technology-based entrepreneurship education: Meeting educational and business objectives. Int. J. Entrep. Innov. 2009, 10, 43-53. [CrossRef]

11. Beckman, C.M.; Eisenhardt, K.; Kotha, S.; Meyer, A.; Rajagopalan, N. Technology entrepreneurship. Strateg. Entrep. J. 2012, 6, 89-93. [CrossRef]

12. Fayolle, A. Entrepreneurship Education at a Crossroads: Towards a More Mature Teaching Field. J. Enterp. Cult. 2008, 16, 325-337. [CrossRef]

13. Cassia, L.; De Massis, A.; Meoli, M. Entrepreneurship research centers around the world: Research orientation, knowledge transfer and performance. J. Technol. Transf. 2014, 39, 376-392.

14. Mian, S.; Lamine, W.; Fayolle, A. Technology Business Incubation: An overview of the state of knowledge. Technovation 2016, 50, 1-12. [CrossRef]

15. Schumpeter, J. The Creative Response in Economic History. J. Econ. Hist. 1947, 7, 149-159. [CrossRef]

16. Malerba, F. Knowledge-Intensive Entrepreneurship and Innovation Systems. Evidence from Europe; Routledge: London, UK; New York, NY, USA, 2010.

17. Prodan, I. A model of technological entrepreneurship. In Handbook of Research on Techno-Entrepreneurship; Therin, F., Ed.; Edward Elgar: Cheltenham, UK, 2007.

18. Villani, E.; Linder, C.; Grimaldi, R. Effectuation and Causation in Science-based New Venture Creation: A Configurational Approach. J. Bus. Res. 2018, 83, 173-185. [CrossRef]

19. Lumpkin, G.T.; Dess, G.G. Clarifying the entrepreneurial orientation construct and linking it to performance. Acad. Manag. Rev. 1996, 21, 135-172. [CrossRef]

20. Allen, K. Entrepreneurship for Scientist and Engineer; Prentice Hall: Upper Saddle River, NJ, USA, 2009. 
21. Ratinho, T.; Harms, R.; Walsh, S. Structuring the Technology Entrepreneurship publication landscape: Making sense out of chaos. Technol. Forecast. Soc. Chang. 2015, 100, 168-175. [CrossRef]

22. Passiante, G.; Romano, A. Creating Technology-Driven Entrepreneurship: Foundations, Processes and Environments; Palgrave Macmillan: Basingstoke, UK, 2016.

23. Secundo, G.; Vecchio, P.D.; Passiante, G. Creating innovative entrepreneurial mindsets as a lever for knowledge-based regional development. Int. J. Knowl. Based Dev. 2015, 6, 276-298. [CrossRef]

24. Henrekson, M.; Rosenberg, N. Designing Efficient Institutions for Science-Based Entrepreneurship: Lesson from the US and Sweden. J. Technol. Transf. 2001, 26, 207-231. [CrossRef]

25. Schaltegger, S.; Wagner, M. Sustainable entrepreneurship and sustainability innovation: Categories and interactions. Bus. Strategy Environ. 2011, 20, 222-237. [CrossRef]

26. Gibb, A. Towards the Entrepreneurial University: Entrepreneurship Education as a Lever for Change. National Council for Graduate Entrepreneurship Policy Paper. Available online: http:/ /irandanesh.febpco. com/FileEssay / karafarin-c-1386-10-30-m21.pdf (accessed on 20 November 2018).

27. Pollard, V.; Wilson, E. The 'entrepreneurial mindset' in creative and performing arts higher education in Australia. Artivate 2014, 3, 3-22.

28. Fayolle, A. Personal views on the future of entrepreneurship education. Entrep. Reg. Dev. 2013, 25, 692-701. [CrossRef]

29. Fayolle, A.; Gailly, B.T.; Lassas-Clerc, N. Assessing the impact of entrepreneurship education programmes: A new methodology. J. Eur. Ind. Train. 2006, 30, 701-720. [CrossRef]

30. Maas, G.; Jones, P. The role of entrepreneurship centers. In Entrepreneurship Centres: Global Perspectives on their Contributions to Higher Education Institutions; Maas, G., Jones, P., Eds.; Palgrave Macmillan: Basingstoke, UK, 2017; pp. 11-16.

31. Finkle, T.A.; Menzies, T.V.; Kuratko, D.F.; Goldsby, M.G. An examination of the financial challenges of entrepreneurship centers throughout the world. J. Small Bus. Entrep. 2013, 26, 67-85. [CrossRef]

32. Finkle, T.A.; Kuratko, D.F.; Goldsby, M.G. An examination of entrepreneurship centers in the United States: A national survey. J. Small Bus. Manag. 2006, 44, 184-206. [CrossRef]

33. Nelles, J.; Vorley, T. Entrepreneurial architecture: A blueprint for entrepreneurial universities. Can. J. Adm. Sci. 2011, 28, 341-353. [CrossRef]

34. Warhuusa, J.P.; Vaid Basaiawmoit, R. Entrepreneurship education at Nordic technical higher education institutions: Comparing and contrasting program designs and content. Int. J. Manag. Educ. 2014, 13, 317-332. [CrossRef]

35. Lackeus, M. Entrepreneurship in Education: What, why, when, how. In Entrepreneurship360 Background Paper; OECD: Paris, France, 2015.

36. Secundo, G.; Ndou, V.; Del Vecchio, P. Challenges for Instilling Entrepreneurial Mindset in Scientists and Engineers: What Works in European Universities? Int. J. Innov. Technol. Manag. 2016, 13, 1640012. [CrossRef]

37. Welter, F.; Lasch, F. Entrepreneurship research in Europe: Taking stock and looking forward. Entrep. Theory Pract. 2008, 32, 241-248. [CrossRef]

38. De Massis, A.; Minola, T.; Viviani, D. Entrepreneurial learning in Italian high-tech start-ups: An exploratory study. Int. J. Innov. Learn. 2012, 11, 94-114. [CrossRef]

39. Wright, M.; Piva, E.; Mosey, S.; Lockett, A. Academic entrepreneurship and business schools. J. Technol. Transf. 2009, 34, 560-587. [CrossRef]

40. Secundo, G.; Passiante, G. An innovative approach to creating business leaders: Evidence from a case study. Int. J. Innov. Manag. Educ. 2007, 1, 214-230. [CrossRef]

41. Duval-Couetil, N. Assessing the impact of entrepreneurship education programs: Challenges and approaches. J. Small Bus. Manag. 2013, 51, 394-409. [CrossRef]

42. Maas, G.; Jones, P. An Overview of Entrepreneurship Education. In Systemic Entrepreneurship: Contemporary Issues and Case Studies; Palgrave Pivot: London, UK, 2015; pp. 22-95.

43. Rae, D.; Martin, L.; Antcliff, V.; Hannon, P. Enterprise and entrepreneurship in English higher education: 2010 and beyond. J. Small Bus. Enterp. Dev. 2012, 19, 380-401. [CrossRef]

44. Edwards, L.J.; Muir, E.J. Promoting entrepreneurship at the University of Glamorgan through formal and informal learning. J. Small Bus. Enterp. Dev. 2005, 12, 613-626. [CrossRef]

45. Matlay, H.; Carey, C. Entrepreneurship education in the UK: A longitudinal perspective. J. Small Bus. Enterp. Dev. 2007, 14, 252-263. [CrossRef] 
46. Wilson, K. Entrepreneurship Education in Europe. In Entrepreneurship and Higher Education; Potter, J., Ed.; OECD: Paris, France, 2008; pp. 1-20.

47. Alberti, F.; Sciascia, S.; Poli, A. The domain of entrepreneurship education: Key issues. Int. J. Entrep. Educ. 2005, 2, 453-482.

48. Fayolle, A.; Gailly, B. From craft to science: Teaching models and learning processes in entrepreneurship education. J. Eur. Ind. Train. 2008, 32, 569-593. [CrossRef]

49. Wright, M.; Siegel, D.S.; Mustar, P. An emerging ecosystem for student start-ups. J. Technol. Transf. 2017, 42, 909-922. [CrossRef]

50. Nambisan, S.; Baron, R.A. Entrepreneurship in innovation ecosystems: Entrepreneurs' self regulatory processes and their implications for new venture success. Entrep. Theory Pract. 2013, 37, 1071-1097. [CrossRef]

51. Isenberg, D.J. How to start an entrepreneurial revolution. Harv. Bus. Rev. 2010, 88, 40-50.

52. Bischoff, K.; Volkmann, C.K.; Audretsch, D.B. Stakeholder collaboration in entrepreneurship education: An analysis of the entrepreneurial ecosystems of European higher educational institutions. J. Technol. Transf. 2017, 43, 20-46. [CrossRef]

53. Gibb, A.A. Concepts into practice: Meeting the challenge of development of entrepreneurship educators around an innovative paradigm: The case of the International Entrepreneurship Educators Programme (IEEP). Int. J. Entrep. Behav. Res. 2011, 17, 146-165. [CrossRef]

54. Keogh, W.; Galloway, L. Teaching enterprise in vocational disciplines: Reflecting on positive experience. Manag. Decis. 2004, 42, 531-541. [CrossRef]

55. Autio, E. Global Entrepreneurship Monitor: 2007 Global Report on High-Growth Entrepreneurship; Babson College: Babson Park, MA, USA, 2007.

56. Gibb, A. Exploring the synergistic potential in entrepreneurial university development: Toward the building of a strategic framework. Ann. Innov. Entrep. 2012, 3, 1-21. [CrossRef]

57. Kirby, D. Entrepreneurship education: Can business schools meet the challenge? Educ. Train. 2004, 46, 510-519. [CrossRef]

58. Liñán, F. The role of entrepreneurship education in the entrepreneurial process. In Handbook of Research in Entrepreneurship Education Cheltenham; Fayolle, A., Ed.; Edward Elgar: Cheltenham, UK, 2007; Volume 1.

59. Edelman, L.; Manolova, T.; Brush, C. Entrepreneurship Education: Correspondence Between Practices of Nascent Entrepreneurs and Textbook Prescriptions for Success. Acad. Manag. Learn. Educ. 2008, 7, 56-70. [CrossRef]

60. Seikkula-Leino, J.; Ruskovaara, E.; Ikävalko, M.; Mattila, J.; Rytkölä, T. Promoting entrepreneurship education: The role of the teacher? Educ. Train. 2010, 52, 117-127. [CrossRef]

61. Ollila, S.; Williams-Middleton, K. The venture creation approach: Integrating entrepreneurial education and incubation at the university. Int. J. Entrep. Innov. Manag. 2011, 13, 161-178. [CrossRef]

62. Barr, S.H.; Baker, T.; Markham, S.K. Bridging the Valley of Death: Lessons Learned From 14 Years of Commercialization of Technology Education. Acad. Manag. Learn. Educ. 2009, 8, 370-388.

63. Lackéus, M. An emotion based approach to assessing entrepreneurial education. Int. J. Manag. Educ. 2014, 12, 374-396. [CrossRef]

64. Etzkowitz, H.; Leydesdorff, L. The dynamics of innovation: From national systems and 'Mode 2' to a triple helix of university-industry-government relations. Res. Policy 2000, 29, 109-123. [CrossRef]

65. EC-European Commission. Education and Training 2020; European Commission: Brussels, Belgium, 2009.

66. Matlay, $\mathrm{H}$. The influence of stakeholders on developing enterprising graduates in UK HEIs. Int. J. Entrep. Behav. Res. 2011, 17, 166-182. [CrossRef]

67. Redford, D.T.; Fayolle, A. Hanbook on the Entrepreneurial University; Edward Elgar Publishing: Cheltenham, UK, 2014.

68. Levie, J. The university is the classroom: Teaching and learning technology commercialization at a technological university. J. Technol. Transf. 2014, 39, 793-808. [CrossRef]

69. Venkataraman, S. Regional transformation through technological entrepreneurship. J. Bus. Ventur. 2004, 19, $153-167$. [CrossRef]

70. Katz, J.A. The institution and infrastructure of entrepreneurship. Entrep. Theory Pract. 1991, 15, 85-102. [CrossRef] 
71. McMillan, S.J. The microscope and the moving target: The challenge of applying content analysis to the World Wide Web. J. Mass Commun. Q. 2000, 77, 80-98. [CrossRef]

72. Audretsch, B.D.; Lehmann, E. Mansfield's Missing Link: The Impact of Knowledge Spillovers on Firm Growth. J. Technol. Transf. 2005, 30, 207-210. [CrossRef]

73. Wright, M.; Clarysse, B.; Mustar, P.; Lockett, A. Academic Entrepreneurship in Europe; Edward Elgar Publishing: Cheltenham, UK, 2007.

74. Guerrero, M.; Urbano, D. The development of an entrepreneurial university. J. Technol. Transf. 2012, 37, 43-74. [CrossRef]

75. Rasmussen, E.A.; Sørheim, R. Action-based entrepreneurship education. Technovation 2006, 26, $185-194$. [CrossRef]

76. Eisenhardt, K.M.; Graebner, M. Theory building from cases: Opportunities and challenges. Acad. Manag. J. 2007, 50, 25-32. [CrossRef]

77. Dutta, S.; Lanvin, B.; Wunsch-Vincent, S. (Eds.) The Global Innovation Index 2015: Effective Innovation Policies for Development; WIPO: Geneva, Switzerland, 2015.

78. Krippendorff, K. Content Analysis: An Introduction to Its Methodology; SAGE: Los Angeles, CA, USA, 2013.

79. Rasmussen, E.; Mosey, S.; Wright, M. The influence of university departments on the evolution of entrepreneurial competencies in spin-off ventures. Res. Policy 2014, 43, 92-106. [CrossRef]

80. Mustar, P. Technology management education: Innovation and entrepreneurship at MINES ParisTech, a leading French Engineering School. Acad. Manag. Learn. Educ. 2009, 8, 418-425.

81. Moon, H.; Mariadoss, B.J.; Johnson, J.L. Collaboration with higher education institutions for successful firm innovation. J. Bus. Res. 2017, in press. [CrossRef]

82. Kassean, H.; Vanevenhoven, J.; Ligouri, E.; Winkel, D.E. Entrepreneurship Education: A Need for Reflection, Real-world Experience and Action. Int. J. Entrep. Behav. Res. 2015, 21, 690-708. [CrossRef]

83. El-Awad, Z.; Gabrielsson, J.; Politis, D. Entrepreneurial learning and innovation: The critical role of team-level learning for the evolution of innovation capabilities in technology-based ventures. Int. J. Entrep. Behav. Res. 2017, 23, 381-405. [CrossRef]

84. Adomako, S.; Opoku, R.A.; Frimpong, K. Entrepreneurs' improvisational behavior and new venture performance: Firm-level and institutional contingencies. J. Bus. Res. 2018, 83, 10-18. [CrossRef]

85. Politis, D.; Gabrielsson, J. Modes of Learning and Entrepreneurial Knowledge. Int. J. Innov. Learn. 2015, 18, 101-122. [CrossRef]

86. Bhave, M.P. A process model of entrepreneurial venture creation. J. Bus. Ventur. 1994, 9, 223-242. [CrossRef]

87. Phan, P.H. The business of translation: The Johns Hopkins University Discovery to Market program. J. Technol. Transf. 2014, 39, 809-817. [CrossRef]

88. Moberg, K.S.; Vestergaard, L.; Jørgensen, C.; Markussen, E.; Hakverdyan, S. How to Assess the Development of Entrepreneurship Education at University Level-The Case of Denmark. In Handbook of the Entrepreneurial University; Fayolle, A., Redford, D.T., Eds.; Edward Elgar: Cheltenham, UK, 2013; pp. 435-459.

89. Popper, K. The Logic of Scientific Discovery; Harper Torchbooks: New York, NY, USA, 1968.

90. Welter, F. Contextualizing Entrepreneurship-Conceptual Challenges and Ways Forward. Entrep. Theory Pract. 2011, 35, 165-184. [CrossRef]

91. Welter, F.; Gartner, W.B.; Wright, M. The Context of Contextualizing Contexts. In A Research Agenda for Entrepreneurship and Context; Welter, F., Gartner, W.B., Eds.; Edward Elgar Publishing: Cheltenham, UK, 2016; pp. 1-15.

92. Urban, B.; Kujinga, L. The Institutional Environment and Social Entrepreneurship Intentions. Int. J. Entrep. Behav. Res. 2017, 23, 638-655. [CrossRef]

93. Refai, D.; Klapper, R. Enterprise Education in Pharmacy Schools: Experiential Learning in Institutionally Constrained Contexts. Int. J. Entrep. Behav. Res. 2016, 22, 485-509. [CrossRef]

(C) 2018 by the authors. Licensee MDPI, Basel, Switzerland. This article is an open access article distributed under the terms and conditions of the Creative Commons Attribution (CC BY) license (http://creativecommons.org/licenses/by/4.0/). 